\title{
Effect of droplet size on coverage of sprayed objects
}

\author{
Wpływ wielkości kropel na pokrycie opryskiwanych obiektów
}

\author{
Antoni Szewczyk, Deta Łuczycka, Zygmunt Owsiak, Beata Cieniawska
}

\section{Summary}

The purpose of the study was to determine the effect of degree of spray the liquid on coverage sprayed on objects by using selected nozzles. The study was conducted in several research institutions. The measurements of droplet size produced by selected spray stream nozzles were performed at Industrial Institute of Agricultural Engineering in Poznań. At the Institute of Agricultural Engineering Wrocław University of Environmental and Life Sciences an experiment of spraying objects placed differently to the spray stream was carried out. An assessment of the degree of coverage spray was performed at the Institute of Plant Protection National Research Institute in Poznan. The results of these tests and analysis showed that the degree of spraying of liquids had an exclusive affect only in the case of horizontal spraying objects. It was proved that, higher degree of spray liquid resulted in higher coverage. In the case of other objects located sprayed spraying impact on the intensity of the coverage was not as unequivocal.

Key words: nozzle, droplet size, coverage degree

\section{Streszczenie}

Celem przeprowadzonych badań było określenie wpływu stopnia rozpylenia cieczy użytkowej na pokrycie opryskiwanych obiektów z zastosowaniem wybranych rozpylaczy. Badania przeprowadzono w kilku ośrodkach naukowych. W Przemysłowym Instytucie Maszyn Rolniczych Poznań wykonano pomiary wielkości kropel wytwarzanych przez wybrane rozpylacze. W Instytucie Inżynierii Rolniczej Uniwersytetu Przyrodniczego we Wrocławiu przeprowadzono eksperyment opryskiwania obiektów różnie usytuowanych w stosunku do rozpylonej strugi. W Instytucie Ochrony Roślin - Państwowym Instytucie Badawczym w Poznaniu oceniono stopień pokrycia opryskanych obiektów. Wyniki tych badań i ich analiza wykazały, że stopień rozpylenia cieczy miał jednoznaczny wpływ jedynie w przypadku opryskiwania obiektów poziomych, gdzie stwierdzono większe pokrycie przy większym stopniu rozpylenia cieczy. W przypadku inaczej usytuowanych opryskiwanych obiektów, wpływ intensywności rozpylenia na stopień pokrycia nie był już tak jednoznaczny.

Słowa kluczowe: rozpylacz, wielkość kropli, stopień pokrycia

\author{
Uniwersytet Przyrodniczy we Wrocławiu \\ Instytut Inżynierii Rolniczej \\ Chełmońskiego 37/41, 51-630 Wrocław \\ antoni.szewczyk@up.wroc.pl
}




\section{Wstęp / Introduction}

Stosowanie środków ochrony roślin jest dotychczas najskuteczniejszym sposobem ochrony upraw przed agrofagami (Pruszyński 2005; Özkan 2008). Przy wykorzystaniu środków ochrony roślin ważnym aspektem jest skuteczność biologiczna pestycydów, która zależy od czynników atmosferycznych, właściwości fizyko-chemicznych cieczy użytkowej oraz parametrów technicznych i technologicznych opryskiwacza oraz rozpylaczy (Kierzek i Wachowiak 2009). Najważniejszym elementem opryskiwacza jest rozpylacz. Od właściwego jego wyboru i doboru parametrów pracy zależy jakość wykonanego zabiegu. Podstawowymi kryteriami oceny pracy rozpylacza są trzy wskaźniki: nierównomierność rozkładu opadu rozpylonej cieczy, stopień pokrycia opryskiwanych obiektów oraz naniesienie cieczy użytkowej (Wachowiak i Kierzek 2007; Nuyttens i wsp. 2009).

Podstawowym celem zabiegu opryskiwania jest uzyskanie jak największej skuteczności w zwalczaniu agrofagów. Skuteczność ta, podobnie jak i poziom zużycia pestycydów oraz bezpieczeństwo w czasie zabiegu, zależy w dużej mierze od jakości rozpylenia cieczy użytkowej. Od wielu lat prowadzone są badania wpływu wielkości kropli na nierównomierność rozkładu opadu rozpylonej cieczy (Lardoux i wsp. 2007; Nuyttens i wsp. 2009; Czaczyk 2012a, b). Badania dotyczyły również wpływu wielkości kropli na znoszenie cieczy opryskowej (van de Zande i wsp. 2008; Czaczyk 2012c). Mimo ukazania się szeregu prac dotyczących zależności między wielkością kropel a pokryciem opryskiwanych obiektów, ciągle brak pełnego wyjaśnienia tej zależności. Wynika to częściowo z dużego postępu, jaki się dokonał w konstrukcji rozpylaczy, a w konsekwencji ukazania się na rynku nowych typów rozpylaczy. W związku z tym powstaje pytanie czy spełniają one oczekiwania, co do jakości pracy, a w szczególności stopnia pokrycia?

Celem przeprowadzonych badań było określenie wpływu wielkości kropel cieczy użytkowej na pokrycie opryskiwanych obiektów z wykorzystaniem wybranych rozpylaczy.

\section{Materiały i metody / Materials and methods}

Badania przeprowadzono $\mathrm{w}$ trzech ośrodkach naukowych. W Przemysłowym Instytucie Maszyn Rolniczych (PIMR) w Poznaniu, Instytucie Ochrony Roślin Państwowym Instytucie Badawczym (IOR - PIB) w Poznaniu oraz w Instytucie Inżynierii Rolniczej Uniwersytetu Przyrodniczego we Wrocławiu.

W PIMR w Poznaniu przeprowadzono pomiar wielkości kropel na laserowym analizatorze widma cząstek „Spraytec” firmy Malvern Instruments. Wielkość kropel mierzona była przez układ optyczny i rejestrowana w pliku dzięki komputerowemu programowi sterującemu. Wartość ciśnienia roboczego ustalono za pomocą elektronicznego manometru o dokładności 0,03 bara. Badania przeprowadzono w stałej temperaturze powietrza wynoszącej $18^{\circ} \mathrm{C}$ i wilgotności względnej $70 \%$. W doświadczeniu wykorzystano wodę wodociagową.
Wyniki pomiarów posłużyły do określenia wartości $\mathrm{Dv}_{(50)}, \mathrm{Dv}_{(10)}$ i $\mathrm{Dv}_{(90)}$. Przeprowadzono ocenę jakości rozpylenia przez określenie jednorodności kropel wytwarzanych przez dany rozpylacz. W obliczeniach zastosowano współczynnik $R_{S}$, obliczony według zależności:

$$
\mathrm{R}_{\mathrm{S}}=\frac{\mathrm{Dv}_{(90)}-\mathrm{Dv}_{(10)}}{\operatorname{Dv}_{(50)}}[-]
$$

$\mathrm{R}_{\mathrm{S}}$ - współczynnik jednorodności rozpylenia [-],

$\mathrm{Dv}_{(90)}$ - średnica, od której krople mniejsze stanowią $90 \%$ objętości cieczy $[\mu \mathrm{m}]$,

$\mathrm{Dv}_{(10)}$ - średnica, od której krople mniejsze stanowią 10\% objętości cieczy $[\mu \mathrm{m}]$,

$\operatorname{Dv}_{(50)}$ - średnica mediany objętościowej kropel [ $\left.\mu \mathrm{m}\right]$ (Czaczyk 2011).

Opryskiwanie obiektów przeprowadzono w Instytucie Inżynierii Rolniczej Uniwersytetu Przyrodniczego we Wrocławiu na autorskim stanowisku badawczym, którego schemat i działanie zostały przedstawione w publikacji Szewczyka i wsp. (2012). Opryskiwano sztuczne rośliny, do których mocowano próbniki w postaci papierków wodoczułych. Próbniki zamocowano w pozycji poziomej i pionowej, poprzecznie i wzdłużnie względem kierunku ruchu rozpylaczy. Sztuczną roślinę przedstawiono na rysunku 1.

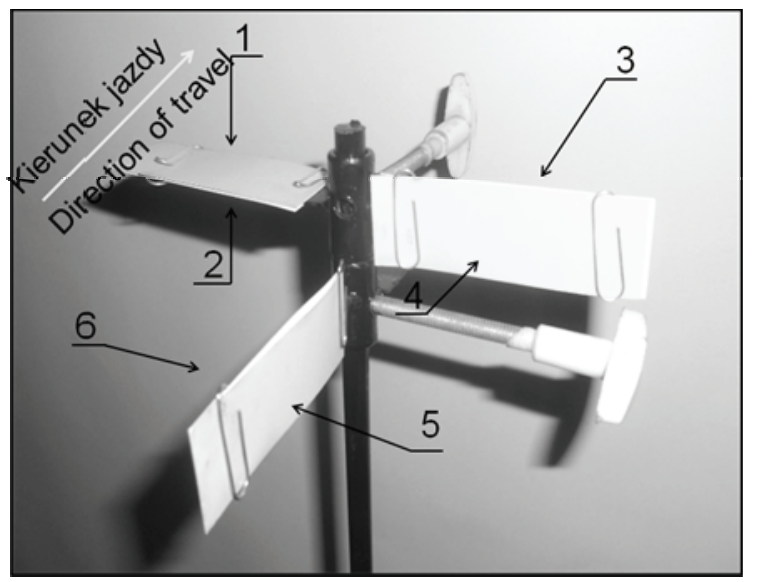

Rys. 1. Widok sztucznej rośliny z zaznaczonymi opryskiwanymi obiektami: 1 - poziomy górny $\left(\mathrm{A}_{\text {pog }}\right), 2$ - poziomy dolny $\left(\mathrm{A}_{\text {pod }}\right), 3$ - pionowy poprzeczny odjazdowy $\left(\mathrm{A}_{\mathrm{oj}}\right), 4-$ pionowy poprzeczny najazdowy $\left(\mathrm{A}_{\mathrm{nj}}\right), 5-$ pionowy wzdłużny prawy $\left(\mathrm{A}_{\mathrm{bp}}\right), 6$ - pionowy wzdłużny lewy $\left(\mathrm{A}_{\mathrm{bl}}\right)$

Fig. 1. View of an artificial plant with marked researched facilities: 1 - upper level $\left(A_{\text {pog }}\right), 2$ - lower level $\left(A_{\text {pod }}\right)$, 3 - vertical transverse leaving $\left(\mathrm{A}_{\mathrm{oj}}\right), 4$ - vertical transverse approach $\left(\mathrm{A}_{\mathrm{nj}}\right), 5-$ vertical longitudinal $\operatorname{right}\left(A_{b p}\right), 6$ - vertical longitudinal left $\left(A_{b l}\right)$

Ocenę stopnia pokrycia opryskiwanych obiektów przeprowadzono w IOR - PIB w Poznaniu na stanowisku laboratoryjnym wyposażonym w mikroskop oraz komputer z oprogramowaniem CSS Video Frame Grabber. Powierzchnia próbników po kontakcie z cieczą użytkową zmieniała swój kolor $\mathrm{z}$ żółtego na granatowy. Stopień pokrycia opryskiwanych powierzchni określano jako 
stosunek powierzchni pokrytej cieczą do całkowitej powierzchni w obszarze pomiaru. Do analizy przyjmowano wycinki próbnika o wymiarach $20 \times 20 \mathrm{~mm}$ w trzech losowo wybranych miejscach. Widok analizowanego próbnika przedstawiono na rysunku 2. Na podstawie wyników stopnia pokrycia wszystkich sześciu próbników o różnej orientacji obliczono średnie pokrycie dla całego obiektu.

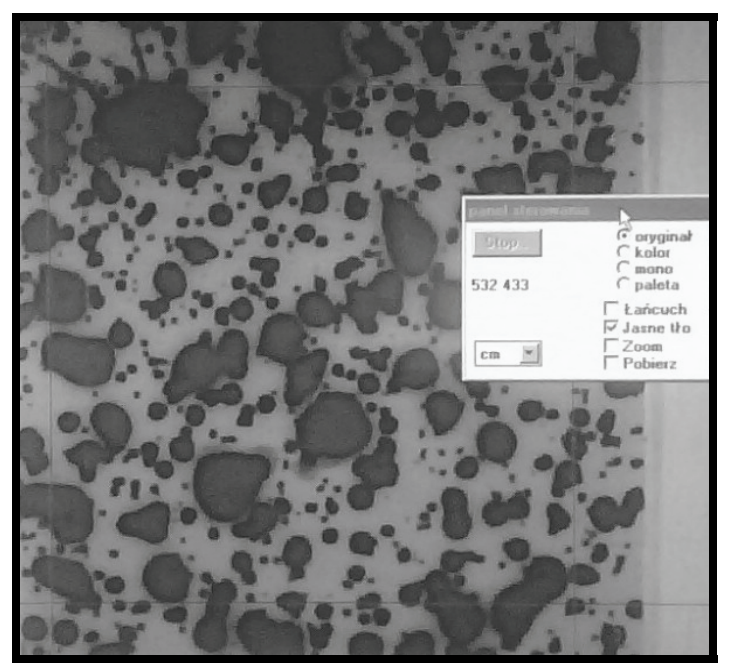

Rys. 2. Widok analizowanego próbnika

Fig. 2. View of analyzed tested

Do badań wybrano następujące rozpylacze: DG, AI, IDK, XR, TJ w rozmiarze 03 i 04 oraz DG i IDK w rozmiarze 05 .

Podczas pomiarów zastosowano następujące parametry i warunki pracy rozpylaczy: stały wydatek $q=1,391 / \mathrm{min}$, ciśnienie cieczy dla rozpylaczy $\mathrm{w}$ rozmiarze $05 \mathrm{p}=$ $0,145 \mathrm{MPa}$, dla rozpylaczy w rozmiarze $04 \mathrm{p}=0,225 \mathrm{MPa}$, dla rozpylaczy o wielkości $03 \mathrm{p}=0,4 \mathrm{MPa}$, wysokość ustawienia rozpylaczy $\mathrm{h}=0,5 \mathrm{~m}$, prędkość opryskiwania $\mathrm{v}=2,78 \mathrm{~m} / \mathrm{s}(10 \mathrm{~km} / \mathrm{h})$.

\section{Wyniki i dyskusja / Results and discussion}

Wyniki pomiarów wielkości kropel przedstawiono w tabeli 1. W tabeli podano podstawowe parametry rozpylonej strugi, takie jak: $\mathrm{Dv}_{(10)} ; \mathrm{Dv}_{(50)} ; \mathrm{Dv}_{(90)}$ oraz obliczony współczynnik $\mathrm{R}_{\mathrm{S}}$. $\mathrm{Na}$ podstawie średnicy mediany objętościowej - $\mathrm{Dv}_{(50)}-\mathrm{VMD}$ (Volume Median Diameter) zaszeregowano również poszczególne stopnie rozpylenia do określonej kategorii kroplistości. Określenie klas, jakie wytwarzają poszczególne rozpylacze w zakresie ciśnień roboczych nawiązuje do ich charakterystyki i do materiałów informacyjnych producentów. Jest również dodatkowym elementem ułatwiającym wybór rozpylacza (Czaczyk 2011). Parametry podane w tabeli 1. różnią się między sobą na tyle, by nawet bez analizy statystycznej można było twierdzić o dostatecznym zróżnicowaniu stopnia rozpylenia cieczy wystarczającym dla potrzeb przeprowadzonych badań.

Rozpylaczem wytwarzającym strugę o najmniejszej wielkości kropel był rozpylacz TJ 11003A, natomiast największą wielkość kropel uzyskano stosując rozpylacz AI 11004, który charakteryzował się również najgorszym współczynnikiem jednorodności rozpylenia. Najlepszym współczynnikiem jednorodności $\mathrm{R}_{\mathrm{S}}$ charakteryzował się rozpylacz DG 11003.

Dla podkreślenia różnic $\mathrm{w}$ stopniu rozpylenia na rysunku 3. pokazano histogramy rozkładów objętościowych frakcji kropel o różnych średnicach, wchodzących w skład rozpylonych strug wybranych rozpylaczy reprezentujących zakres stosowanych w praktyce kategorii kroplistości (F, M i XC).

Wykresy te umożliwiają określenie objętości rozpylonej cieczy w danej frakcji i na tej podstawie ocenę przydatności rozpylacza do określonego zabiegu. Jak wiadomo, frakcje kropel mniejszych niż $100 \mu \mathrm{m}$ mogą stanowić zagrożenie wynikające ze znoszenia, a frakcje większe od $500 \mu \mathrm{m}$ również uważane są za niekorzystne, gdyż może dochodzić do ociekania cieczy (Kierzek 2011; Czaczyk 2012a).

Tabela 1. Charakterystyka badanych rozpylaczy

Table 1. Characteristics of tested nozzles

\begin{tabular}{|c|c|c|c|c|c|c|}
\hline \multirow{2}{*}{$\begin{array}{c}\text { Rozpylacz } \\
\text { Nozzle } \\
\text { ISO }\end{array}$} & \multirow{2}{*}{$\begin{array}{c}\text { Ciśnienie cieczy } \\
\text { Liquid pressure } \\
{[\mathrm{MPa}]}\end{array}$} & $\operatorname{Dv}_{(10)}$ & $\mathrm{Dv}_{(50)}-\mathrm{VMD}$ & $\mathrm{Dv}_{(90)}$ & \multirow{2}{*}{$\frac{\mathrm{R}_{\mathrm{S}}}{-}$} & \multirow{2}{*}{$\begin{array}{c}\text { Kategoria kroplistości } \\
\text { Classification } \\
\text { ASAE }\end{array}$} \\
\hline & & \multicolumn{3}{|c|}{$[\mu \mathrm{m}]$} & & \\
\hline DG 11005 & 0,145 & 189,8 & 410,3 & 723,0 & 1,300 & $\mathrm{VC}$ \\
\hline IDK 12005 & 0,145 & 232,8 & 524,6 & 964,5 & 1,395 & $\mathrm{XC}$ \\
\hline AI 11004 & 0,225 & 238,6 & 572,1 & 1090,0 & 1,488 & $\mathrm{XC}$ \\
\hline IDK 12004 & 0,225 & 196,3 & 426,0 & 781,9 & 1,375 & $\mathrm{VC}$ \\
\hline DG 11004 & 0,225 & 144,9 & 305,2 & 498,3 & 1,158 & M \\
\hline XR 11004 & 0,225 & 123,3 & 254,8 & 415,3 & 1,146 & $\mathrm{M}$ \\
\hline TJ 11003A & 0,400 & 102,5 & 212,7 & 339,5 & 1,114 & $\mathrm{~F}$ \\
\hline DG 11003 & 0,400 & 123,5 & 257,6 & 408,0 & 1,104 & M \\
\hline IDK 12003 & 0,400 & 152,8 & 316,0 & 558,3 & 1,283 & $\mathrm{M}$ \\
\hline AI 11003 & 0,400 & 192,9 & 443,3 & 829,2 & 1,435 & $\mathrm{VC}$ \\
\hline
\end{tabular}


a)

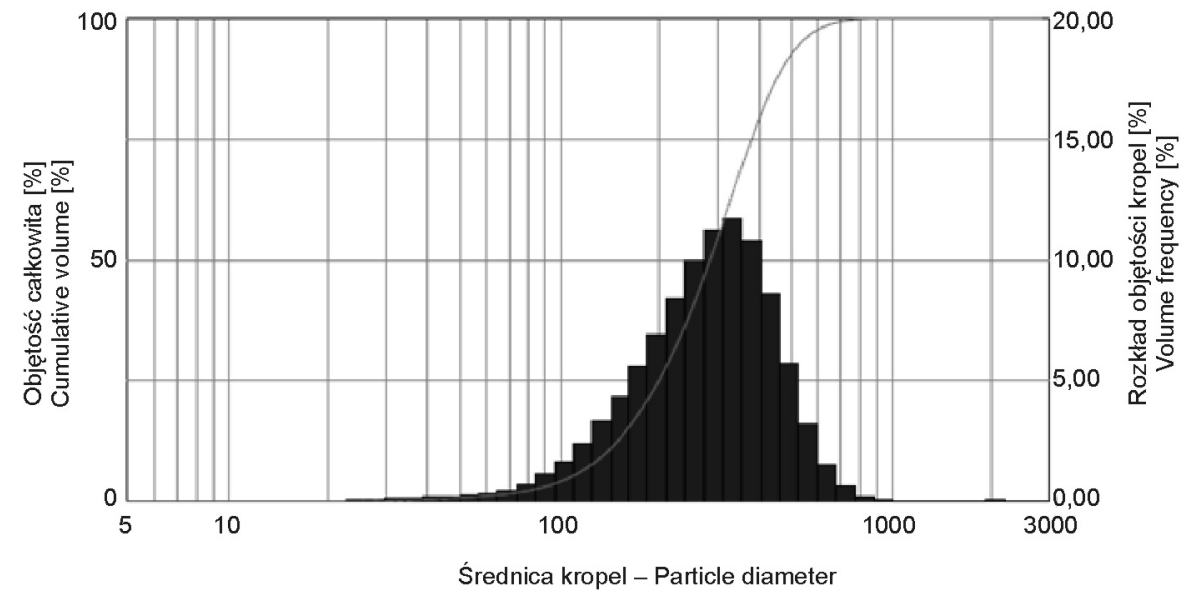

b)

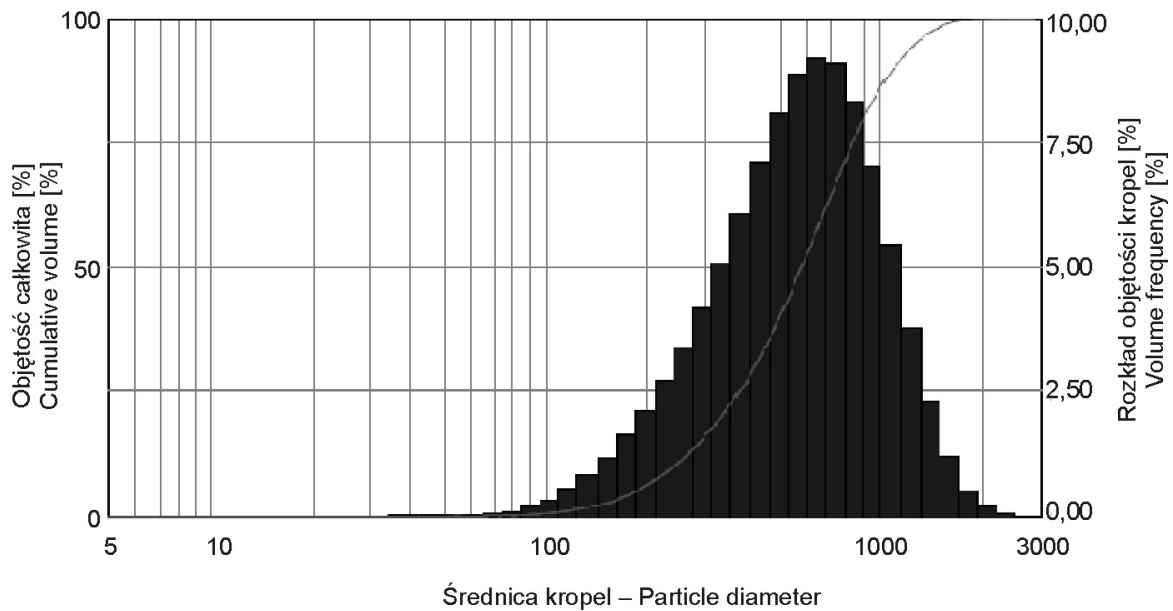

c)

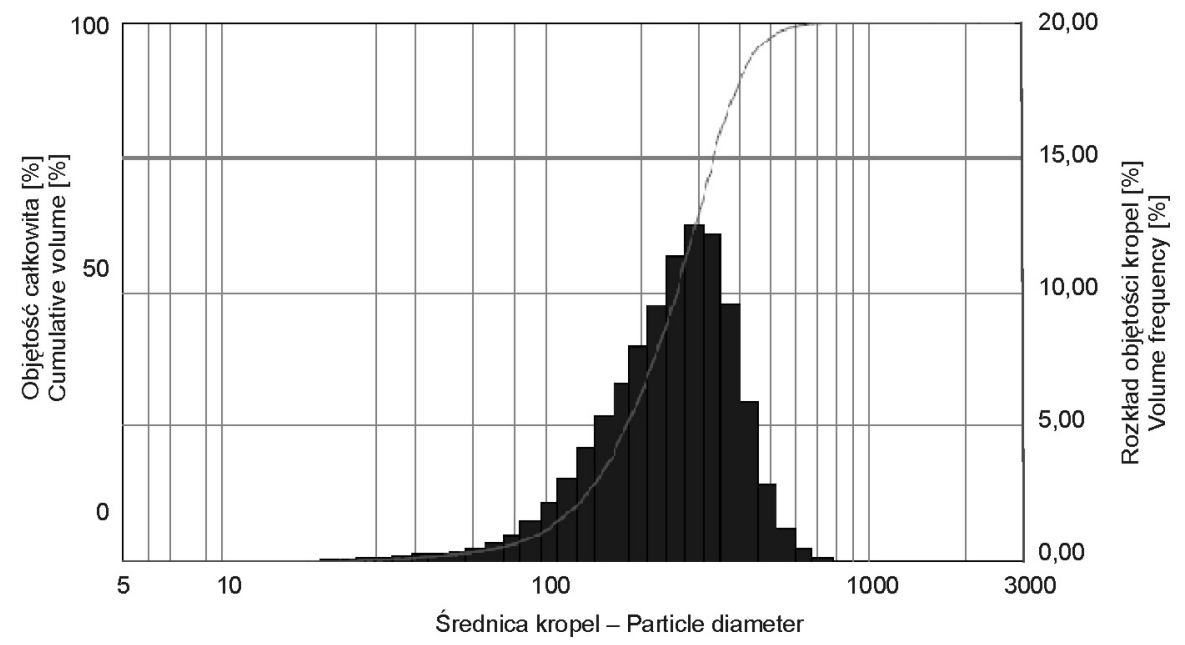

Rys. 3. Objętościowy rozkład wielkości kropel: a) TJ 11003A, b) AI 11004, c) DG 11003

Fig. 3. Volume distribution of droplet size: a) TJ 11003A, b) AI 11004, c) DG 11003

$\mathrm{Na}$ rysunkach 4-7 przedstawiono stopień pokrycia opryskiwanych obiektów $\mathrm{z}$ zastosowaniem różnej wielkości kropel cieczy wyrażonej średnicą mediany objętościowej VMD. W prezentowanych wynikach nie pokazano stopnia pokrycia obiektu poziomego dolnego, gdyż w żad- nym analizowanym przypadku nie uzyskano zauważalnych śladów pokrycia tego obiektu. Na rysunku 4. przedstawiono wielkość pokrycia obiektów poziomych górnych, czyli powierzchni najbardziej wyeksponowanej na opad rozpylonej cieczy. Oceniając ogólną tendencję, jaką daje 
się zauważyć na tym wykresie można stwierdzić, że im większe rozpylenie, tym większy uzyskiwany jest stopień pokrycia. Jest to potwierdzenie znanej zależności udokumentowanej wynikami wielu dotychczasowych badań. Po wnikliwej analizie prezentowanych wyników na rysunku 4. widać, że mogą istnieć odstępstwa od tej reguły. W przypadku porównania rozpylaczy AI i IDK widać, że większe krople z rozpylacza AI dają większy stopień pokrycia opryskiwanych obiektów poziomych górnych. Wyjaśnienie tego zjawiska, prawdopodobnie związane jest $\mathrm{z}$ różnym sposobem tworzenia się kropli w rozpylaczach eżektorowych o odmiennej konstrukcji i wymaga odrębnych badań wykraczających poza zakres niniejszej pracy.

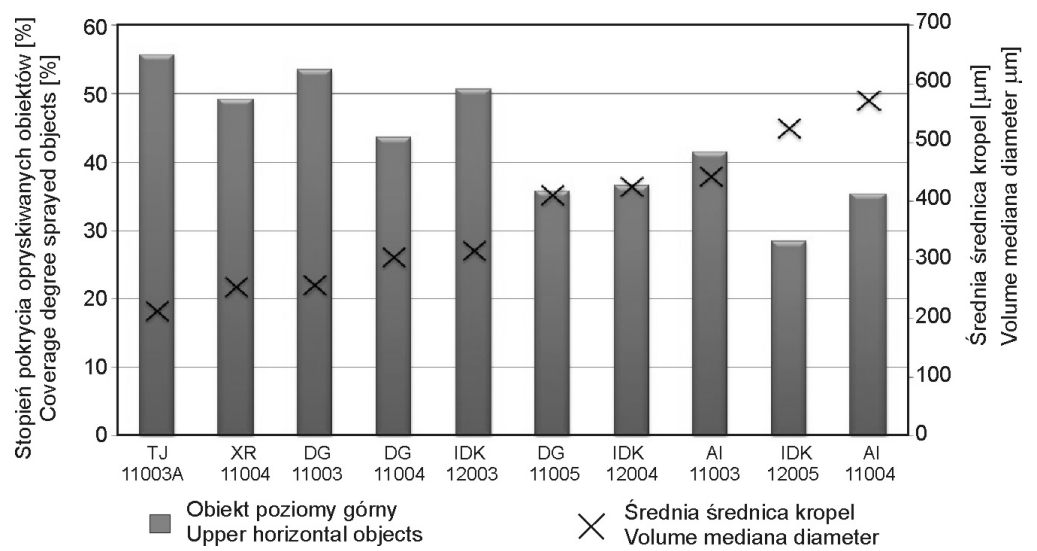

Rys. 4. Wielkość kropli a stopień pokrycia obiektów poziomych górnych

Fig. 4. The droplet size and the degree coverage of the upper horizontal objects

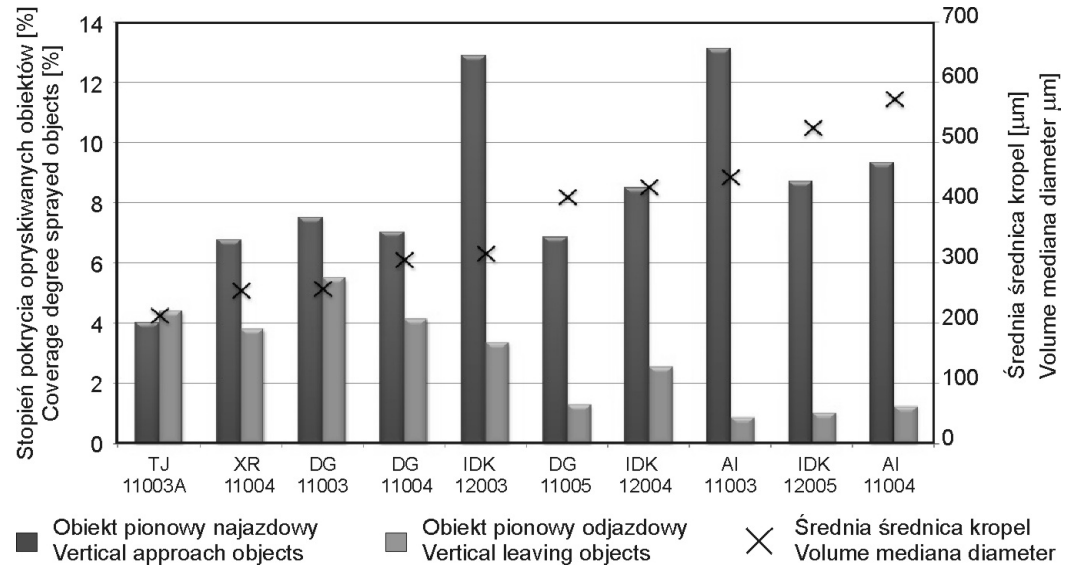

Rys. 5. Wielkość kropli a stopień pokrycia obiektów pionowych poprzecznych

Fig. 5. The droplet size and the degree coverage of the transverse vertical objects

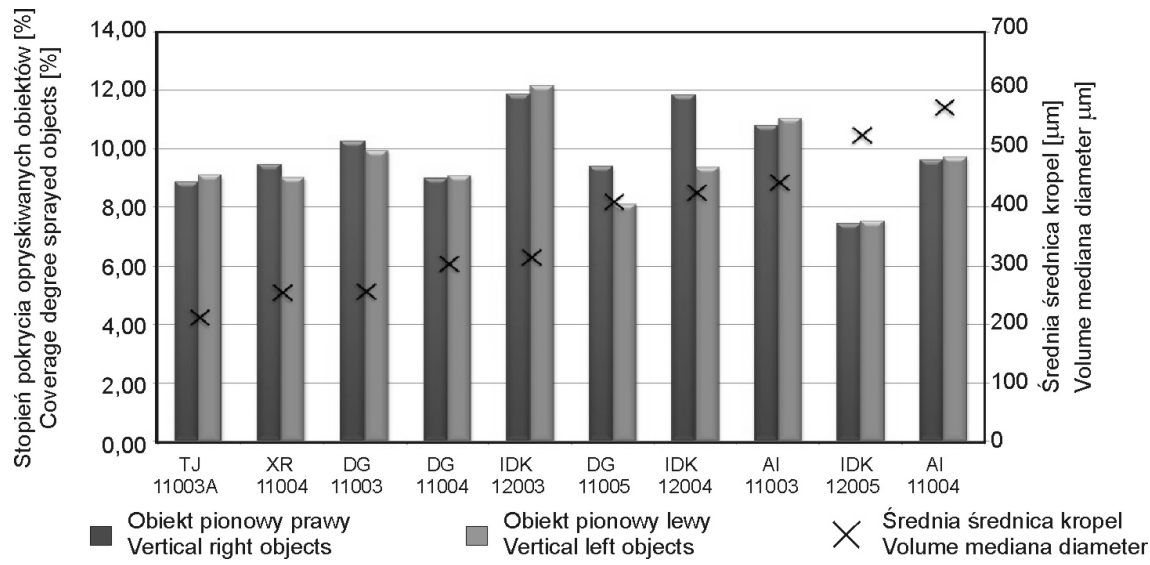

Rys. 6. Wielkość kropli a stopień pokrycia obiektów pionowych wzdłużnych

Fig. 6. The droplet size and the degree coverage of the longitudinal vertical objects 


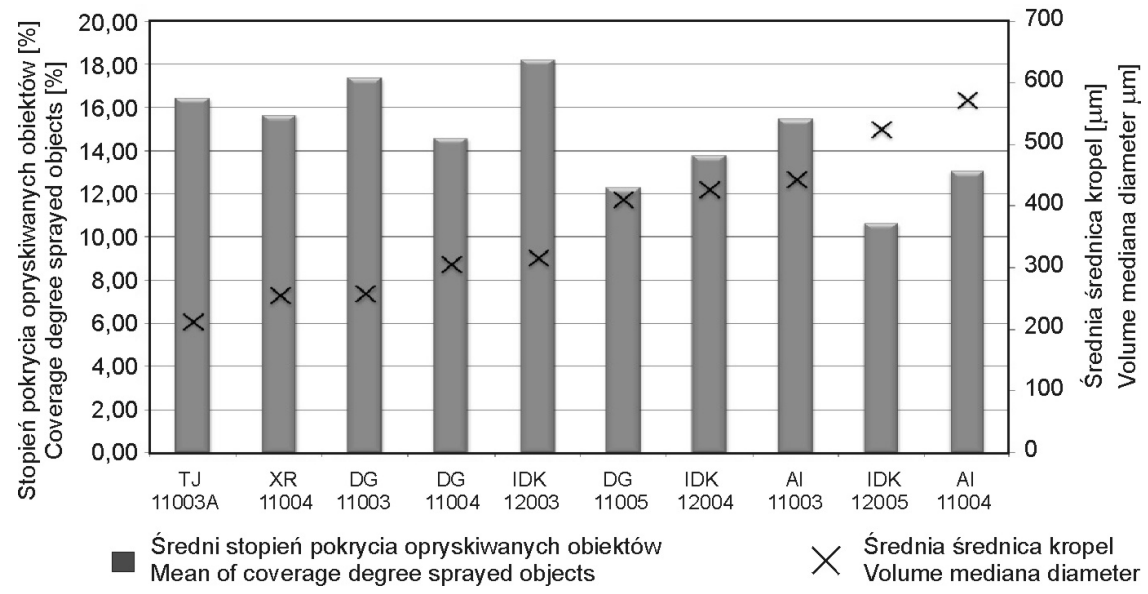

Rys. 7. Wielkość kropli a średni stopień pokrycia opryskiwanych obiektów

Fig. 7. The droplet size and the mean degree of coverage sprayed objects

$\mathrm{Na}$ rysunku 5. przedstawiającym stopień pokrycia obiektów pionowych poprzecznie ustawionych do kierunku opryskiwania nie widać wyraźnej przewagi kropli drobnych, jeżeli chodzi o ich zdolność pokrycia obiektów pionowych najazdowych. W tym przypadku większe pokrycie zaobserwowano dla kropli większych.

Pomocna w wytłumaczeniu tego zjawiska może być analiza trajektorii kropel. Te większe poruszając się z większą prędkością wynikającą z prędkości początkowej przy wylocie $\mathrm{z}$ rozpylacza oraz poziomej wynikającej z ruchu opryskiwacza mają, jak widać, większe zdolności pokrywania powierzchni pionowej najazdowej będącej ich naturalną przeszkodą $\mathrm{w}$ locie $\mathrm{w}$ porównaniu z kroplami mniejszymi wytracającymi dość szybko swoją prędkość w wyniku oporu powietrza (Szewczyk i Wilczok 2007).

W przypadku opryskiwania obiektów usytuowanych zgodnie $\mathrm{z}$ ruchem rozpylacza zaobserwowana tendencja była podobna, jak dla obiektów poziomych. Przy ocenie stopnia pokrycia obiektów pionowych usytuowanych wzdłużnie nie stwierdzono wyraźnej zależności pokrycia od wielkości rozpylenia cieczy (rys. 6).

$\mathrm{Na}$ rysunku 7. pokazano średni stopień pokrycia opryskiwanych obiektów - w zależności od średnicy mediany objętościowej VMD. Zastosowanie tego wskaźnika w metodyce badań miało na celu uzyskanie ostatecznej odpowiedzi na pytanie - czy stopień rozpylenia cieczy ma jednoznaczny wpływ na stopień pokrycia opryskiwanych obiektów? Takiej wyraźnej prawidłowości nie stwierdzono analizując przedstawiony na rysunek 7 . Może to oznaczać, że taka wyraźna tendencja nie istnieje lub zastosowany w metodyce wskaźnik średniego pokrycia dla wszystkich opryskiwanych obiektów nie spełnia oczekiwań. Jednak jest to dowód na to, że potrzebne są prace, których celem byłoby znalezienie metody opisującej całościowo proces nanoszenia cieczy użytkowej na opryskiwane rośliny i umożliwiającej wyciaganie trafnych wniosków odnośnie doboru rozpylaczy dostosowanych swoim działaniem do warunków zabiegu.

$\mathrm{Na}$ podstawie danych $\mathrm{z}$ literatury przedmiotu (Czaczyk 2011; 2012a, 2012b) można wnioskować, że konstrukcja współczynnika jednorodności rozpylenia $R_{S}$ wskazuje na jego przydatność do oceny rozpylaczy pod względem ich zdolności do pokrycia opryskiwanych obiektów. Mimo, że celem pracy było określenie wpływu wielkości kropli na pokrycie, to autorzy oczekiwali po uzyskanych wynikach, że współczynnik Rs będzie również determinował potencjał rozpylonej strugi do pokrywania opryskiwanych obiektów. Te oczekiwania nie zostały potwierdzone uzyskanymi wynikami badań.

\section{Wnioski / Conclusions}

Na podstawie uzyskanych wyników badań i ich analizie sformułowano następujące wnioski:

1. W przypadku opryskiwania obiektów poziomych zaznaczył się wyraźny wpływ stopnia rozpylenia cieczy na pokrycie - im większe rozpylenie cieczy tym większy stopień pokrycia.

2. Zastosowany w badaniach wskaźnik określany w metodyce jako średni stopień pokrycia opryskiwanych obiektów nie umożliwił stwierdzenia wyraźnej zależności między rozpyleniem a pokryciem opryskiwanych obiektów.

3. Współczynnik jednorodności rozpylenia $\mathrm{R}_{\mathrm{S}}$ okazał się mało przydatny do oceny rozpylaczy pod kątem ich zdolności do pokrycia opryskiwanych obiektów.

\section{Literatura / References}

Czaczyk Z. 2011. Wstępne wyniki oceny jakości pracy rozpylaczy eżektorowych MMAT. Technika Rolnicza Ogrodnicza i Leśna 6: 10-12. Czaczyk Z. 2012a. Charakterystyka użytkowa wybranych rozpylaczy płaskostrumieniowych do ochrony upraw polowych. J. Res. Appl. Agric. Engin. 57 (2): 31-40. 
Czaczyk Z. 2012b. Charakterystyka użytkowa wybranych rozpylaczy do ochrony upraw przestrzennych. J. Res. Appl. Agric. Engin. 57 (2): $23-30$.

Czaczyk Z. 2012c. Potencjał znoszenia cieczy wybranych rozpylaczy płaskostrumieniowych mierzony w tunelu aerodynamicznym. J. Res. Appl. Agric. Engin. 57 (2): 41-46.

Kierzek R. 2011. Reakcja roślin jednoliściennych na herbicydy w zależności od techniki opryskiwania i właściwości cieczy użytkowej. Rozpr. Nauk. 26, Inst. Ochr. Roślin - PIB, Poznań, 124 ss.

Kierzek R., Wachowiak M. 2009. Wpływ techniki ochrony roślin na skuteczność wykonywanych zabiegów. Probl. Inżyn. Rol. 2: 75-81.

Lardoux Y., Sinfort C., Enfaltand P., Sevila F. 2007. Test method for boom suspension influence on spray distribution. Part II: Validation and use of a spray distribution model. Biosystems Engin. 96 (2): 161-168.

Nuyttens D., de Schampheleire M., Verboven P., Brusselman E., Dekeyser D. 2009. Droplet size-velocity characteristics of agricultural sprays. Trans. ASABE 52 (5): 1471-1480.

Özkan H.E. 2008. Technological solution to problems associated with application of pesticides. J. Agric. Machines Sci. 4 (2): $193-198$.

Pruszyński S. 2005. Plant protection in Poland: Past, present and future. Annu. Rev. Agric. Eng. 4 (1): 11-20.

Szewczyk A., Łuczycka D., Cieniawska B., Rojek G. 2012. Porównanie stopnia pokrycia obiektów opryskiwanych wybranymi rozpylaczami eżektorowymi - jedno i dwustrumieniowym. Inż. Rol. 2 (136): 325-334.

Szewczyk A., Wilczok G. 2007. Teoretyczny i rzeczywisty rozkład cieczy dla wybranych parametrów ustawienia rozpylaczy. Inż. Rol. 9 (96): 265-271.

van de Zande J.C., Huijsmans J.F.M., Porskamp H.A.J., Michielsen J.M.G.P., Stallinga H., Holterman H.J., de Jong A. 2008. Spray techniques: how to optimize spray deposition and minimize spray drift. Environmentalist 28: 9-17.

Wachowiak M., Kierzek R. 2007. Wpływ nowoczesnych systemów opryskiwania na jakość pokrycia cieczą użytkową roślin ziemniaków. [Effect of new spray equipments on the leaf coverage in potato]. Prog. Plant Prot./Post. Ochr. Roślin 47 (1): $150-154$. 